DOI: https://doi.org/10.47405/mjssh.v7i1.1258

\begin{tabular}{|c|c|}
\hline 4 & Malaysian Journal of Social Sciences and Humanities (MJSSH) \\
\hline $\begin{array}{l}\text { Malaysian Journal of } \\
\text { Social sciences and }\end{array}$ & Volume 7, Issue 1, January 2022 \\
\hline (MJ-sSH) & e-ISSN : 2504-8562 \\
\hline & $\begin{array}{l}\text { Journal home page: } \\
\text { www.msocialsciences.com }\end{array}$ \\
\hline
\end{tabular}

\title{
Malaysian Electoral System Reform and the Challenges of its Implementation After the 14th General Election
}

\author{
Mohamad Fairuz Mat Ali'1, Mohammad Agus Yusoff ${ }^{1}$ \\ 1Faculty of Social Sciences and Humanities, Universiti Kebangsaan Malaysia (UKM), Malaysia \\ Correspondence: Mohamad Fairuz Mat Ali (fairuzmatali@gmail.com)
}

\begin{abstract}
Prior to the $14^{\text {th }}$ general election (GE-14), electoral practices in Malaysia have been often criticised as being obscure and biased since it was plagued with issues such as dubious voter registers and ballot paper fraud. Therefore, in its manifesto during GE-14, Pakatan Harapan (PH) promised to reform this electoral practice to make it more independent, transparent, and fair. PH then won the GE-14 on the strength of this vow, forcing it to keep its manifesto pledge. However, implementing the said promise is not easy as most of the proposals involve amendments to the Federal Constitution that require the support of at least a two-thirds majority. The fact that PH lacks such a majority has raised the issue of whether or not the objective to reform the electoral system can be materialised. Thus, this article examines the aspects of electoral reform implemented by $\mathrm{PH}$ during its 22 months in power and assesses the challenges faced in implementing such electoral system reform. The concept of electoral reform was used as an analytical tool in this article. This article mainly obtained its data from secondary sources including books, journals, theses, official government documents and websites, while primary data were collected from unstructured interviews with authoritative informants. Findings revealed that among the important reforms of the country's electoral system that have been accomplished by $\mathrm{PH}$ are improving the standard operating procedures of elections, enhancing election rules that do not require amendments, amending laws that require simple majority support in the parliament, and implementing 'high-impact' electoral reforms that require amendments to the Federal Constitution. Moreover, it was also discovered that the main challenge to reforming the electoral system was the constraint of electoral rule amendments that require the approval of a two-thirds majority of parliamentarians. Other obstacles included politicians' unwillingness to accept a new electoral system culture, barriers to accessing data and information owned by other agencies, discrepancies between federal and state legislation, and financial constraints on improving existing hardware and systems necessary for electoral reform success.
\end{abstract}

Keywords: electoral system, reform, Pakatan Harapan, Malaysia, GE-14

\section{Introduction}

Democracy is a system of government determined by the people through an electoral process. To have legitimacy, an election must be conducted freely and fairly. Meanwhile, elected leaders must rule for the benefit of the people. This statement is in line with the popular dictum of the $16^{\text {th }}$ President of the United States who stated that democracy is a government of the people, by the people, for the people. When these criteria are met, then the country is considered to have a democracy, following the 
common understanding that democracy is a government ruled by the people that rely on looking after the interests of the citizens.

The question is, how to implement a free and fair election? This is important to note since a fair and free election must be free from any elements of fraud and vote manipulation that could disrupt its level of integrity. Voter registers whose information is questionable and invalid ballot papers are among the forms of manipulation that makes an election unfair. In addition, the manipulation of constituency delimitation (or gerrymandering) that gives an advantage to the ruling party and the malapportionment of voters between constituencies are examples often related to unfair elections. For example, Ong et al. (2017: 118) asserted that malapportionment is contrary to the principle of one person, one vote, which is the main criterion in a modern representative democracy system. This example shows that electoral injustice is not only subject to the process involved during the election but also matters before an election is held.

In Malaysia, various allegations of electoral misconduct have been raised by civil society and the public during the $\mathrm{BN}$ rule, such as a drastic increase in the number of voters in a constituency, voter registers whose information is questionable, manipulation of the partisan vote through gerrymandering and malapportionment, and the use of government organisations for the benefit of the BN party ahead of elections (Ufen, 2013: 6-7; Wong, 2018: 68). Similarly, the $14^{\text {th }}$ general election (GE-14) was not spared from being manipulated by the BN government to ensure their victory.

This has prompted the opposition party Pakatan Harapan (PH) to promise electoral institution reform as its manifesto if it wins the GE-14 on the ground of restoring the people's trust in the democratic system in Malaysia through the implementation of transparent and fair elections. The proposed reform covers the aspects of appointment of members, transparency of election procedures, voter registration, campaign period and delimitation of constituencies (PH, 2018: 59-60). Following PH's victory in GE14, the people demanded that the promise of electoral reform be fulfilled so that future elections will have more integrity, transparency, and fairness. Nevertheless, implementing such reforms was proven more difficult than anticipated, since there are many hurdles and problems that must be overcome. Hence, those challenges are discussed in this paper.

\section{Rethinking Election and The Electoral System}

This article used the concept of electoral reform as its analytical tool since it is very closely related to the title of this article, which discusses the challenges of electoral system reform in Malaysia after the GE-14. Nonetheless, before discussing the electoral system, this article first presents the concept of elections as the two are highly related. Elections are often associated with the practice of democracy since they provide an opportunity for every citizen to elect a representative among themselves to form a government as an implementor to realise the aspirations and demands of the people.

Electing a representative involves an election that is freely and fairly conducted. Therefore, every electoral system needs to have effective electoral laws covering the process before, during and after the election to ensure that the elections are free from any form of injustice and malpractice. Dahl (1971: 4) in his book Polyarchy: Participation and opposition stated that free and fair election is one of the main pillars in developing a democratic political system. Although he did not describe the concept of free and fair in detail, scholars have later employed the concept to come up with ideal electoral characteristics.

Elklit and Svensson (1997: 36-39) refer the phrase free to the rights and opportunities for citizens to participate and make their choices during elections, while the phrase fair refers to equal treatment and opportunity to participate in elections either as a voter, supporter or contesting candidate. Meanwhile, Streb (2008: 3-5) on the other hand outlined that free and fair elections should have the following four characteristics. First, each qualified individual carries the same value of votes through the division of constituencies that have approximately equal voter density rates. Second, all individuals or parties contesting have an equal chance of winning without the existence of a dominant party controlling the 
election. Third, each vote is secret and the public, as well as the contesting parties, are allowed to observe the course of the election process. Fourth, there must be procedures that make it easy for citizens to register as voters and exercise their rights.

Bishop and Hoeffler (2016) in their article Free and fair elections: A new database outlined 10 characteristics of free and fair elections. First, elections are held in a fixed cycle of periods, as well as citizens are free to compete and make choices during elections. Second, the existence of an independent electoral body. Third, the availability of easy access for voters to vote during polling day. Fourth, citizens can easily register as voters and use up-to-date and accurate voter registers during elections. Fifth, every qualified citizen has the opportunity to compete and that the rejection of nomination is made based on a valid justification. Sixth, a campaign period is free from government interference and that all parties are free to speak out and hold rallies. Seventh, equal media access for all parties and candidates competing. Eighth, a fair voting process without the occurrence of elements of ballot paper fraud and voting is carried out without the intervention of any party agent. Ninth, election officials must comply with all election rules and laws besides providing equal opportunities to all party representatives, local as well as international observers to monitor the voting process. Finally, the vote tallying process is monitored by more than one group of observers, whereas the acceptance or rejection of ballot papers must be done based on clear rules and regulations without any element of partisanship and fraud.

An election that adopts the above characteristics can provide a fair and equal space for each party contesting, thus increasing the level of trust and participation of the people in the electoral process. Nevertheless, such perfection can only be achieved if election governing bodies, political parties, the judiciary, election monitoring teams, legislatures and voters play an effective role (Bishop \& Hoeffler, 2016). This is because their attitudes and actions during the election process determine the level of integrity of an election.

Looking at the electoral landscape in Malaysia, its electoral system is always questioned and accused of being full of misconduct, obscurity, and unfairness. Not only that but the Election Commission (EC) is also labelled as a body that is not independent and under the tutelage of the ruling party that wants to maintain its power. The addition of fake ballot papers, polling on the working days, short campaign periods and voter registers whose information is questionable are among the electoral practices that are seen to give an advantage to the ruling party. On the issue of misconduct, the people demanded that the electoral system in the country be reviewed and improved to make it more transparent and fairer.

What is electoral reform? Katz (2005: 58-60) defines the electoral system as "... changes in the electoral systems" encompassing aspects of “... wholesale replacement of the electoral formula of national electoral systems" and "... minor changes in the electoral system as the alteration of ballot access requirements or a change from one proportional representation formula to another." Utilising this definition, Katz refers electoral reform to two aspects. First, the replacement of the existing electoral system to a different electoral system. Second, amendments or improvements to some aspects of the existing electoral system such as voter registration and voting procedures, methods of redistribution of constituencies, and campaigning rules aimed at improving the process in a more systematic direction.

Leyenaar and Hazan (2011: 441) defined it as "... any change in the (electoral) rules that leads to a change in the operation of the electoral system," indicating that electoral reform is any change in the electoral rules that give impact on existing electoral system practices. To include, amendments to the eligibility requirements for voters' registration, the regulations that must be complied with by voters at the polling station, the manner in which ballot papers are marked, and the procedure for determining a contesting candidate's victory. They also asserted that electoral reform includes the replacement of the existing electoral system with a new system as it involves amendments to laws and electoral procedures. 
In short, electoral reform is the act of changing, amending and improving existing electoral practices to make them better, which can be implemented either by replacing the entire electoral system under practised with a new electoral system or a selective reform on some of the procedures or rules provided in the existing electoral process. Nonetheless, this selective reform is not only subject to the process during the voting or election, but also involves the process before and after the election such as the demarcation of constituency boundaries, voter registration, nomination and management of election petitions.

Various purposes have been explained for this electoral system reform. According to Norris (2011), its purpose is to complete the process of democratisation of a country to overcome the weaknesses that exist in the political system. For example, in Italy in 1993, electoral reforms were implemented to address the weaknesses of the political system at the time that was tainted by acts of corruption, causing the people to lose faith in the course of elections in the country. This is because the Italian elections were dominated by the Christian Democratic Party with an absolute majority from 1946 to 1992 resulting in public doubts on the accountability of the elections and the government at that time. Thus, it can be assumed that electoral reform is one of the methods to increase the level of public confidence in elections, including the country's electoral institutions.

Besides, the national election procedure prioritises the freedom of the people to make choices and vote. This situation occurred in Indonesia during the New Order era under the rule of President Suharto who was infamous for electoral misconduct. Under Suharto, he allowed only three political parties to compete, controlled the election governing body, and obligated bureaucrats as well as the military to vote for him during general elections (Agustino, 2013: 255-259). This situation made the election in Indonesia to be unfair since the action has violated the civil liberties and political rights of its citizens. Following the fall of Suharto in 1998, New Order election laws were amended to allow the country's electoral governing body to have the independence and authority to conduct matters related to Indonesian elections. The amendment also removed restrictions on political parties to compete and contest in elections and gave citizens the freedom to vote and guaranteed the secrecy of their votes. Indonesia's move to a more democratic state began with post-New Order electoral reform, which ensured free, fair, and inclusive elections for all people (Morgenbesser \& Pepinsky, 2018: 12).

Furthermore, electoral reform is pertinent to improve the efficiency of the election process to keep pace with today's technology and information system development. This measure can improve the election process so that its implementation would be faster and easier. According to Tokaji (2008: 5556), reforms on voter registration procedures utilising technological developments have a positive impact on the election process as online registration has increased the number of new voters, citizen participation during polling day and voter awareness on elections. The use of information technology can avoid errors caused by human negligence and thus increase the level of integrity of the election body as well as the people's trust in an election.

Additionally, electoral reform occurs as a result of public pressure to alter the present electoral system, which is seen as incompetent and obscure. For example, electoral reforms in New Zealand in 1993 and Italy in 1994 were driven by people's pressure to demand a better electoral system. Malaysia is also experiencing a similar trend since the manipulation of constituency boundaries, large voter gaps between constituencies, vote-buying, vote fraud, voter registers that are not updated and contain false voter information become among the allegations often thrown by the people, opposition parties and civil society against the election process in the country. Apart from that, the fairness of the existing electoral system was also criticised when the BN party still held the reins of government despite failing to gain the highest percentage of votes during the general election. This situation further strengthened the demand for electoral reform in the Malaysian elections.

The success of the coalition of parties in PH to overthrow the BN regime in the GE-14 on May 9, 2018 , is the best opportunity for the people to observe the reform of the electoral system in Malaysia. In its election manifesto in GE-14, PH promised to create a check and balance system, rebuild the dignity of public administration, and restore the people's trust in public institutions. However, implementing the electoral system reform as promised was no easy task especially when the reform 
requires amendments to the Federal Constitution that demands the support of at least two-thirds of the votes of the members of the Dewan Rakyat, which the PH government did not have. Thus, it raises the question of the extent to which these electoral reform aspirations can be implemented. This article discusses the challenges of implementing electoral reform by the PH government after the GE-14.

\section{Literature Review on Electoral System Reform}

Scholars have undertaken substantial research on the electoral system in the past with their focus on the practice of the electoral system, the factors influencing electoral reform, and the people's dissatisfaction with the justice, transparency, and integrity of the electoral system in their respective countries.

Stockton (2010) in his article entitled How rules matter: Electoral reform in Taiwan discussed electoral reform in Taiwan that has replaced its electoral system from a single non-transferable vote system in multi-member districts to a majority system in 2004. He mentioned that the factor influencing Taiwan to reform its electoral system was the issue of unfair division of seats and votes between the big and small parties in the country. This is because the mechanism of the previous electoral system allows a party to field more than one candidate to contest in the same constituency, and at the same time, voters could only vote for one candidate. This scenario created competition and provocation among party members and caused a split of votes among candidates of the same party as voting is not focused on the party, but more on individual candidates. As a result of this system, small parties have a greater chance of gaining victory as they did not face competition among members and only need to obtain a simple majority vote to get one seat. Hence, a new election system was created to overcome the aforementioned difficulties.

Although the reforms implemented produced positive impacts such as a significant reduction in the number of parliamentary seats from 225 to 113 seats, the electoral reforms did not address previously unresolved concerns, which included uncompetitive competition amongst competing parties. In contrast, the Taiwan Nationalist Party (also known as the Kuomintang) emerged as the dominant party topping over $50 \%$ of the vote and parliamentary seats. The new system shows that inter-party competition is only focused on the two main parties, which are the Taiwan Nationalist Party and the Progressive Democratic Party, compared to the implementation of the previous system that allowed minority parties to contest and win a constituency. It turned out that the reforms implemented did not achieve the expected objectives since the adaptation of a simple majority system only benefited large and strong parties such as the Taiwan Nationalist Party.

Hellman (2014) in his article Electoral reform in Asia: Institutional engineering against 'money politics' examined the reform of the electoral system in three Asian countries, namely Japan in 1994, Thailand in 2001, and Taiwan in 2008. Previously, the electoral system in the three countries was marred by issues of money politics and corruption, thus forcing the people to demand changes on the electoral system in their countries. The reforms implemented illustrated that the representative system in the countries is no longer focused on individual party candidates, but changed to party-based elections by the concept of a multi-member majority system. Although the implementation of the new system has succeeded in creating a systematic electoral process in the three countries, the issues of money politics and corruption have yet to be fully addressed. According to Hellman (2014), such reforms failed to curb the culture of money politics that had become ingrained in politicians. Electoral issues such as corruption, vote-buying and violence that existed before the era of electoral reform are still ongoing.

Electoral reform also took place in Indonesia after the fall of Suharto's autocratic regime in 1998. Agustino (2013) in his book Pendemokrasian di Indonesia: Kelahiran, penyebaran dan kematangan kesedaran politik explored the Indonesian election post-New Order era. He revealed that after the fall of Suharto, Indonesia reformed its electoral system by setting up the Seven Team Commission to conduct studies on aspects of elections that need to be reformed as a measure to create a more democratic Indonesia. As a result of the Commission's proposal, Indonesia's electoral system was 
amended by establishing an independent electoral body, abolishing the provision of 'free seats' to the Indonesian National Army in parliament, more open participation for all political parties participating in elections, the repeal of laws that obligate civil servants and the military to vote for government parties, and improvements on electoral laws. On top of that, the mechanisms of electing the president and representatives have also been changed when the people were allowed to directly vote for the president for the first time in 2004 compared to the previous period where the power to vote was only allocated to members of parliament. Subsequently, the mechanism of electing members of parliament was also changed in 2009 from a proportional election system to a simple majority system so that the people could elect a representative who is 'closer' to their hearts. According to Agustino (2013), the electoral reforms implemented have given people the freedom to choose to make party competition in elections more competitive, thus nurturing the practice of democracy in Indonesia.

Besides Asian countries, the electoral system in the United States (US) has also undergone a process of reform. Hall (2013) in his article US voter registration reform examined the reform of the US voter registration process after the 2000 election, which is the method of registration on polling day. $\mathrm{He}$ discovered that the strategy has significantly decreased the number of voters who were unable to vote because their names were not listed in the electoral roll despite having registered with agencies appointed by the election authority. The method also increased the level of people's participation in elections owing to its mechanism that makes it easy for voters to register and vote at the polling station at the same time. He concluded that the reform of the voter registration and voting process in the US had succeeded in increasing the level of public participation in elections, especially among the youth.

In Malaysia, Tey (2010) in his article entitled Malaysia's electoral system: Government of the people? discussed the need for electoral reform in Malaysia to restore the people's trust in the legitimacy of the country's political system. This is because there are weaknesses in the practice of elections in Malaysia, especially from the legal aspect. Among them is the provision on the appointment of Election Commission (EC) members that are only generally stated in Article 114 (2) of the Federal Constitution, namely "...shall have regard to the importance of securing an Election Commission which enjoys public confidence." He stated that this provision contains a requirement that obligates the EC to be independent in carrying out its responsibilities without the influence of any party. However, the nature of such freedom is also limited by the Federal Constitution when the EC does not have the authority to decide the boundaries of constituencies. More intriguingly, if the prior boundary suggestion is not approved by the Dewan Rakyat, the prime minister has the authority to consult with the EC about amending the new boundary recommendation. According to him, the inconsistency in this legislative provision permits the party backed by the prime minister to force the EC to change the gerrymandering of boundaries to maintain their hegemony. Tey (2010) also criticised the election petition administration, claiming that election court orders cannot be appealed in federal courts, that the governing party may utilise government finances and machines for their campaign, and that official media coverage is skewed toward the ruling party.

Based on the weaknesses presented, Tey (2010) proposed that electoral reform in Malaysia should begin with amendments to election-related provisions in the Federal Constitution, the country's highest source of legislation. He also advocated that all acts and regulations governing the conduct of elections are revised as part of the Federal Constitution's amendments to strengthen the national electoral system's processes and boost public confidence in national elections. All arguments and weaknesses discussed by Tey in his article show the existence of loopholes and discrepancies in the provisions of the existing electoral law that have an impact on the implementation of elections in terms of autonomy, transparency and justice. Although Tey (2010) stressed the need for electoral reform to correct the common practices, he did not discuss the challenges faced by the EC in making the reform a success. Thus, this lacuna becomes the core of discussions in this article.

Dettman and Gomez (2019) in their article Political financing reform: Politics, policies and patronage in Malaysia presented the need to introduce and enforce laws related to political financing in Malaysia. They suggested that each political party declare the source and expenditure of their respective party funds as well as set asset ownership limits for each party as a measure to address the issue of corruption, vote-buying and money politics that were rampant during the BN rule. 
Additionally, they proposed that electoral reforms regarding election financing should be implemented to rein in the abuse of government power through public funds to finance party activities during campaigns and election days, such as paying wages to on-duty party machines and providing financial incentives to out-of-constituency voters to return to vote. This 'soul-buying' move indirectly instils a sense of indebtedness that ultimately drives voters to support the party. This is one of the factors that result in an unfair election since it closes the opportunity for opposition parties that do not have a financial advantage to win the hearts of voters. Although the article is intriguing, Dettman and Gomez (2019) did not detail the difficulties faced by PH in implementing these electoral system reforms, enabling this article to fill in those gaps.

\section{Research Methodology}

This article employed qualitative design owing to its flexible nature and suitability in examining the phenomenon studied, namely the challenges of the implementation of electoral reform in Malaysia post-GE-14. The main method of data collection was through secondary sources obtained by library research using books, journal articles, official parliamentary statements, newspapers, government documents such as the Federal Constitution, acts and regulations related to elections.

This method of data collection enabled the researcher to critically review, interpret, and analyse the data to create the arguments presented in this article. The advantage of the secondary data collection method is that it saves cost and energy since it does not involve data collection through questionnaires or surveys. Furthermore, this method facilitated the author to collect data and information as it involved existing documents that can be found online and in the Tun Sri Lanang Library of Universiti Kebangsaan Malaysia, Centre for Research, Politics and International Affairs, Faculty of Social Sciences and Humanities Library, and Election Commission Library, Putrajaya.

In addition, information were obtained from primary sources through unstructured interviews with two authoritative informants, namely Dato Seri Mahdzir Khalid, the rural development minister and Mohamad Sabu, a former minister during the PH rule and also a Kota Raja parliamentarian. This method is more flexible as it is carried out through informal conversations and focuses on the information needed by the author. This data indirectly allows the authors to supplement the pool of study information that cannot be obtained through document content analysis.

All data collected were analysed qualitatively. This analysis did not involve numerical data, but the information that have been collected were analysed to answer the purpose for which this article was written. Each data was analysed to evaluate the challenges faced by the EC in implementing the electoral reform and the challenges faced by the EC in realising the electoral reform. Babbie (2014) outlined that among the advantages of the qualitative analysis method is that the author can discuss the study in more depth based on data obtained from various documents. This in turn allows the analysis to be done in more detail to achieve its objectives.

\section{Findings and Discussion}

\section{Electoral System Reform under the PH Government}

In the GE-14 campaign, $\mathrm{PH}$ promised to implement electoral reforms if it wins the general election to improve the country's electoral system that is often plagued with issues of legal loopholes and injustice. These issues are often raised in every election to urge the people to force and demand the government to reform the existing electoral process so that it would become more efficient, free, transparent, and fair.

According to Khoo (2014: 87), the electoral reform movement began as a reaction to the opposition party's displeasure with the 2004 general election. BN's victory at that time was marred by various electoral misconduct controversies including electoral boundaries manipulation and ballot fraud. This 
issue has prompted Democratic Action Party (DAP), Parti Keadilan Rakyat (PKR), Parti Islam SeMalaysia (PAS), Parti Sosialis Malaysia, Parti Nasional Sarawak and BERSIH to demand free and fair elections. Since then, BERSIH has been aggressively sharing information to the public through social media platforms such as Facebook and WhatsApp messaging about electoral anomalies such as boundary manipulation, phantom voters, and voter registers with dubious information. The effort succeeded in increasing the awareness of the people when three series of demonstrations held in 2007, 2011 and 2012 were attended by a large crowd reaching up to 30 thousand people (Khoo, 2014: 97). Due to the weaknesses of the EC, PH promised to carry out electoral reforms if it wins in GE-14.

After winning GE-14, PH reformed the electoral system as promised in the manifesto of the Buku Harapan. The first reform implemented by the $\mathrm{PH}$ government was to break the tradition of appointing EC members. Prior to this, EC members were appointed from among retired civil servants who hold the highest positions in government bodies. After GE-14, the composition of the EC membership began to be diversified by appointing not only individuals from among retired civil servants, but also professional services, civil society representatives, and even academics. The appointment of new EC members was made by the PH government following the resignation of the previous EC members, namely chairman, Che Mohd Hashim Abdullah on 1 July 2018, and his deputy, Othman Mahmood along with five other EC members, namely Md Yusop Mansor, Abdul Aziz Khalidin, Sulaiman Narawi, K Bala Singam and Leo Chong Cheong on the $1^{\text {st }}$ January 2019 (SPR, 2019a).

With the resignation of the EC leadership, the PH government appointed new leadership to lead the EC, namely Azhar Azizan Harun a lawyer as chairman, together with the other members including Dr Azmi Sharom a former University of Malaya lecturer as deputy chairman, Ramlan Ibrahim former Secretary-General of the Ministry of Foreign Affairs, Chin Phaik Yong former Director-General of the Manpower Department, Zoe Randhawa former BERSIH activist, Dr Mohd Faisal Syam Abdol Hazis former Head of the Center for Asian Studies at Universiti Kebangsaan Malaysia, and Awang Sahari E.M Nadzeer former Deputy Commissioner of Sabah State Police (SPR 2019a). All new members of the EC were appointed by the Yang di-Pertuan Agong as provided for in Article 114 of the Federal Constitution.

Unfortunately, the opposition party criticised the decision, claiming that PH had broken its vow to fill all critical positions via the legislative approval procedure. Mahdzir Khalid (2021), minister of rural development, stated:

$\mathrm{PH}$ violated its manifesto commitment. $\mathrm{PH}$ stood on the promise of appointing crucial positions via the legislative process, but once in power, all of its commitments were abandoned. That is why the public was enraged, and the administration crumbled in only 22 months. It was only natural that the $\mathrm{PH}$ administration succumbed for ridiculing its manifesto, much to the anger of the public. Additionally, the public also suffered under the PH regime. The majority of its bases are indifferent to the condition and life of its citizens.

Although PH did not fulfil its promise to appoint EC members through the parliamentary process, the appointment remained valid and not contrary to the requirements of the constitution. The only drawback is that this appointment has a moral deficit since PH appointed EC members without fulfilling their promises. Mohamad Sabu (2021), former defence minister and Kota Raja parliamentarian in an interview with him defended the PH government's decision:

Although the PH government's actions are contrary to its promise of reforms, this is a good start to liberalising EC membership by appointing individuals from various backgrounds with expertise in electoral affairs. Openness in the appointment of EC members is a good step to ensure that the election governing body is lined up by individuals who are independent in politics and experts in election management. This aspect is important for making the EC a trusted election governing body and has the credibility to conduct elections in a transparent, fair, and independent manner. 
Regardless of the views of political observers on the appointment of EC members, its chairman, Azhar Azizan Harun, stated that the EC will implement this reform from four main aspects. First, by improving the standard operating procedures of elections. Its implementation is an administrative order under the jurisdiction of the EC that does not involve any constitutional amendment or require parliamentary approval. Consequently, any improvements can be implemented from time to time and practised immediately in any election. Second, by enhancing the election rules under the jurisdiction of the EC, which does not require amendments to the election rules. This improvement certainly does not involve amendments to election rules such as the Election Regulations (Registration of Voters) 2002, the Election Regulations (Postal Voting) 2003 and the Election Regulations (Conduct of Elections) 1981. According to the law, any amendment to the election rules must be laid in the session of the Dewan Rakyat for the attention of the assembly members, which is in line with section 17 of the Election Act 1958.

Third, by amending laws that require simple majority support in the Dewan Rakyat. Among the election laws involved under this category are the Election Offenses Act 1954, the Election Commission Act 1957 and the Election Act 1958. Fourth, by amending any provision in the Federal Constitution that requires the support of at least a two-thirds majority of the members of the Dewan Rakyat. Improvements under this fourth category involve a long period as the amendments require the support of a two-thirds majority vote in the Dewan Rakyat.

After GE-14, various reforms on procedures of standard electoral operation were implemented by the EC. First, two dedicated channels were provided for senior voters aged 60 and above. For this purpose, channels 1 and 2 at the respective polling station were reserved for senior citizens with a maximum limit of 350 voters per channel. Second, new voting channels were added at polling stations that have a large number of voters. The Sungai Kandis by-election saw its implementation in line with the EC's action by reducing the number of voters in each channel from 750 to 600 people to avoid congestion and shorten the waiting period in each channel. Third, the voting period was extended from 8.00 am to $5.30 \mathrm{pm}$ compared to $5.00 \mathrm{pm}$ previously. Fourth, the election process was broadcast live through the EC's Facebook page (BERSIH, 2019; EC, 2018). This initiative becomes a virtual electoral education platform for the people to know the real situation during the election process. Apart from that, it also shows the transparency and fairness of the country's election process - something that the people have been demanding for so long.

Fifth, the EC improved the election procedure by distributing voter's cards to all registered voters ahead of the election for the constituency. The card contains information about the polling station, voting channel, voter number, as well as the recommended date and time for voters to vote so that those who receive the card do not need to queue at the EC bar to verify the information since they can proceed directly to their assigned voting channels. Sixth, the EC also implemented the method of registering and updating voting addresses online through the MySPR Daftar application (Bernama, 2019; EC, 2019b). This new mechanism simplifies and saves time as voters no longer have to fill in forms manually and submit them at any EC representative office or counter. Through this system, there will be no issue of individuals being denied the right to vote for failing to appear at the EC counter to apply as registered voters. Seventh, the EC has been increasingly open to sharing information on election procedures with the public. Alerts are disseminated through major and alternative media channels such as online news portals, television, newspapers, and radio (EC, 2018). This move makes the public better understand the election process, thus closing the space for any party to manipulate information and spread negative allegations.

In addition, the $\mathrm{PH}$ government has implemented 'high-impact' electoral reforms that require amendments to the Federal Constitution. To mention a few, the Dewan Rakyat sitting on 16 July 2019 and the Dewan Negara sitting on 25 July 2019 both made history by approving three amendments to the Federal Constitution in support of the Vote18 initiative, which included automatic voter registration and the age limit for voting and appointment as a Dewan Rakyat candidate being adjusted to 18 years old (Dewan Negara Malaysia, 2019: 77; Dewan Rakyat Malaysia, 2019: 170). The Vote18 reform recommendation received more than two-thirds of the support vote from both houses, which 
shows the open attitude of the opposition party in accepting electoral improvements that benefit the country's democracy.

One of the Vote18 initiatives approved includes an amendment to Article 47 and Section 5 of the Eighth Schedule, Federal Constitution on lowering the age limit for Dewan Rakyat candidates from 21 to 18 years. The amendment opens space for participation and the right to speak for the youth to jointly formulate national policy at the legislative level. In addition, the initiative also provides an opportunity for each party to shape and educate future leaders. However, this parliamentary approval does not include the proposed electoral reform to lower the age limit from 21 to 18 years for State Assembly candidates. This is because the change in the age limit for state legislative representatives is subject to the state government to amend the state constitution. Therefore, nominations for state seats remain at the minimum age limit of 21 years until the states amend their respective state constitutions.

Looking at the electoral reforms implemented to date, most of the improvements to the electoral system are implemented under the first category, which is on the standard operating procedures of elections under the jurisdiction of the EC since the amendment can be implemented immediately without being notified or presented in the Dewan Rakyat.

Nevertheless, there are still many promises of electoral reform that have not been fulfilled by PH. Among them is the separation of EC functions into several different entities including the EC being made the parent body that specialises in the enforcement of election laws, the establishment of two other bodies each focuses on the matter of conducting elections, and the implementation of revaluation on the boundaries of constituencies. In addition, the EC has not yet replaced the simple majority system, set minimum-maximum number of voters for each constituency, caretaker government guidelines, and extension of the campaign period. One of the main factors that hindered the EC from succeeding in electoral reform was the position of the PH and the subsequent government that did not have a two-thirds majority in the Dewan Rakyat to facilitate the passage of electoral reform proposals. Several other challenges and obstacles or aspects are discussed in the next section.

\section{Challenges of Implementing Electoral Reform}

The first challenge faced by the PH in implementing electoral reform is that some of the promised reforms require amendments to the Federal Constitution as well as the electoral acts. The amendment requires parliamentary approval either by a simple majority or a two-thirds majority. Among the recommendations involved include changes in the method of appointing EC members, separation of EC functions, setting a minimum-maximum limit on the number of constituencies and the replacement of the simple majority system.

The second challenge is the lack of commitment from the National Alliance (Perikatan Nasional-PN) government to implement such reforms after replacing the PH government. This is because the promise of reform was made by the PH government before being overthrown by the PN only after 22 months of ruling the country. Mohamad Sabu (2021) in an interview with him gave the following argument about the challenge of reforming this electoral system:

The PN government is not bound by the electoral reforms promised by the PH. If the PN government agrees to proceed with the reform of this electoral system, it will certainly give political mileage to $\mathrm{PH}$. Thus, for political survival, the PN government that replaced $\mathrm{PH}$ showed no interest in pursuing the reform of this electoral system. This is because electoral reform is a promise of the PH manifesto, not the PN. Therefore, if the proposal is continued by the PN government and become successful, the PN government must be worried that $\mathrm{PH}$ will use the success of this reform to regain the people's trust in the GE- 15 .

The third challenge is the need to gain majority support in the Dewan Rakyat and Dewan Negara. Looking at the position of PN that only has a simple majority vote of 114 seats in the Dewan Rakyat, 
the number is only sufficient to approve amendments to the act, but inadequate to approve amendments to the Federal Constitution that requires at least a two-thirds majority or 148 majorities of parliamentarians. The proposed electoral reforms that require the approval of a two-thirds majority to approve amendments to the Federal Constitution are the replacement of a simple majority system to a proportional representation system involving the amendment of Article 116, separation of EC functions requiring amendments to Article 113, new EC member appointment mechanism involving amendments to Article 114, the fixing of a limit on the number of voters for each constituency involving the amendment of the Thirteenth Schedule, and the fixing of the election date on a particular day or date involving the amendment of Article 55 (4). These five proposals cannot be realised unless the constitution is first amended with the support of a two-thirds majority of parliamentarians.

The fourth challenge is the unwillingness of politicians to accept the reform on the electoral process. Among the factors is that these reforms created a need for new campaigns, approaches, and education to the voters. In this regard, Rahat and Hazan (2011: 479) in their article The barriers to electoral system reform discovered that among the challenges of system reform is the reluctance of the ruling party or opposition to accept a new environment of the electoral procedure. This is because the party is comfortable with the mechanism in place and wants to maintain the victory of their respective parties according to the 'culture' of the existing electoral system. Thus, this situation tends to create resistance from parties to accept changes that are unfavourable to them. This view can be referred to that by Norris (2011: 544) who considers the level of acceptance of political parties towards electoral reform as dependent on the extent to which the new electoral process can consolidate power and maximise their victory.

This can be seen through the recommendation to replace the existing simple majority electoral system with a system of proportional representation. A simple majority system is more likely to give victory to a large and influential party in a constituency regardless of the popular vote, which is why $\mathrm{BN}$ has been able to remain in power since the 2008 general election even though they do not have the popular vote. $\mathrm{BN}$ is more synonymous and closer to rural voters who have fewer voters; this resulted in most of the seats being won by the party in rural areas. The use of a proportional representation system that relies on popular votes threatened BN's declining hegemony. Therefore, BN was not interested in giving up the simple majority system that has helped them in winning 13 consecutive general elections. In addition, the mechanism of the proportional representation system gave $\mathrm{PH}$ an advantage to control the reins of government leadership as it managed to control the popular vote in GE-13 and GE-14 by more than 50\% at the parliamentary level. The National Council of Professors confirmed that the proportional representation system gives an advantage to opposition parties, especially DAP, which can obtain an additional 60 seats should this system be introduced (Irwan, 2020). This is because the Chinese vote support is higher for DAP compared to the Malay vote that is split into several different parties. This finding is certainly a major factor for $\mathrm{BN}$ and other parties to reject electoral reform to replace the simple majority system with a proportional representation system.

The fifth challenge is the collective cooperation between the EC and several other government agencies. Performing voter registration, updating voting information and cleaning the voter register requires the EC to access the information stored in the database of the National Registration Department (NRD), Prison Department, Ministry of Health Malaysia and Royal Malaysia Police (PDRM) (Mohd Nasaruddin, 2019; EC, 2019c). However, it is not easy for the EC to obtain this information because of the sensitivity and confidentiality of the information that must be maintained by each agency to prevent it from being misused or manipulated by irresponsible parties. Therefore, in ensuring the success of the proposed electoral reform, every government agency possessing data authority such as the NRD must be prepared to cooperate and share data openly with the EC. This step is required so that every qualified citizen can be registered and that their information is updated automatically using authentic data owned by the NRD.

The sixth challenge is the legal hurdle since there are legal differences under the jurisdiction of the central government and the state government. This situation can be seen in the case of allowing 18year-old voters to contest for the Dewan Rakyat and State Legislative Assembly (DUN) seats. The recommendation to lower the age limit for parliamentary candidates has already been approved by the 
federal government through amendments to Article 47 and Section 5 of the Eighth Schedule, Federal Constitution. However, the same approval does not apply to the reduction of the age limit for DUN member candidates as the provisions for such conditions are outlined under the State Constitution of each state. Therefore, the reduction of the age limit from 21 years to 18 years for DUN candidates can only be implemented after the state government amends the relevant legal provisions.

The seventh challenge is financial and hardware allocation constraints. The reform of the electoral process, especially those involving the use of information technology systems and computerised applications, requires substantial allocations. For instance, the implementation of Vote18 will affect the increase in the number of voters from 14.9 million during GE-14 to 22.7 million by 2023. If the implementation of GE-14 costs RM500 million to manage 14.9 million voters nationwide, GE-15 will require a much higher expenditure between RM750 million to RM800 million (Bernama, 2020). The increase of 50\% would affect the increase in the cost of management, equipment and election staff that needs to be doubled from GE-14. In addition, other improvements to election procedures such as the increase in the number of channels for each congested polling station and the distribution of voter cards would also contribute to the increased cost of election management. The recommendation on electoral reform to register voters automatically also requires significant expenditure as it involves the development of a more stable online system besides the provision of more sophisticated computer hardware to accommodate the election procedure.

Although the above discussions addressed the challenges of implementing electoral system reform, there are also reform proposals by the PH government that can be easily implemented by the next government. The two proposals are the extension of the campaign period to a minimum of 21 days and the enforcement of a cooling-off period before polling day, which do not involve any amendment to the federal constitution that requires the approval of a two-thirds majority but only involves amendments to Section 3 (1) of the Election Regulations (Conduct of Elections) 1981, which are under the jurisdiction of the EC. These amendments only need to be informed to the members of the Dewan Rakyat through an announcement during the conference.

\section{Conclusion}

During the BN rule, there were many allegations of the EC's weaknesses in conducting free and fair elections. Thus, in the $14^{\text {th }} \mathrm{GE}$ campaign, the $\mathrm{PH}$ coalition of opposition parties promised to reform the electoral system should they win the election. After winning it, PH fulfilled its promise to improve the electoral system. The analysis found that the PH has made numerous improvements to the country's electoral system during its 22-month rule, including two major changes: the liberalisation of the EC membership through the appointment of professionals such as lawyers, NGO activists, and retired civil servants; and the approval of the Vote18 motion to lower the voting age and the nomination of Dewan Rakyat members 21 to 18 years besides automatic voter registration. The implementation of these initiatives put the EC in line with developed countries such as Australia and New Zealand, which expand the democratic voice of the people by providing opportunities for 18-year-old voters to participate in elections and speak in the legislature.

In addition, the EC also implemented improvements to standard election operating procedures under its jurisdiction such as the distribution of voter cards before the election, setting up special channels for senior citizens and disabled voters as well as reducing the number of voters at the polling station. These improvements have been implemented by the EC since before the GE-14.

Nevertheless, there are still many reform recommendations that have not been implemented as the government must first amend the federal constitution before it can be implemented. Among them are the change in the method of appointing EC members, the division of EC functions, the setting of a minimum-maximum limit on the number of constituencies and the replacement of the simple majority system. Such obstacles can only be overcome when each party, whether the government or the opposition, can ignore the issues of politics and focus on improving the practice of democracy in the country by approving electoral reforms tabled to the parliament. 


\section{Acknowledgement}

The authors would like to thank Universiti Kebangsaan Malaysia for funding this study through UKM Research Grants Code SK-2020-005 and SK-2020-015 and to the Faculty of Social Sciences and Humanities, UKM for providing facilities to conduct this research.

\section{References}

Agustino, L. (2013). Pendemokrasian di Indonesia: Kelahiran, penyebaran dan kematangan kesedaran politik. Bangi: Penerbit Universiti Kebangsaan Malaysia.

Babbie, E. (2014). The basics of social research. Ed. ke-6. Belmont, CA: Wadsworth Cengage Learning.

Bernama (2019, 2 November). SPR: Masa mengundi dipanjangkan sampai 5.30 petang. Malaysiakini. https://www.malaysiakini.com/news/498309

Bernama (2020, 28 February). Kos PRU antara RM750j hingga RM800j. Berita Harian. https://www.bharian.com.my/berita/nasional/2020/02/660435/kos-pru-antara-rm750j-hinggarm800j

BERSIH (2019). Laporan pemerhatian pilihan raya kecil P078 Cameron Highlands. http://www.bersih.org/wp-content/uploads/2019/01/Laporan-Pemerhatian-Pilihan-Raya-KecilP078-Cameron-Highlands.pdf

Bishop, S. \& Hoeffler, A. (2016). Free and fair elections: A new database. Journal of Peace Research, 53(4), 608-616.

Chi, E. (2014). Two party contests and the politics of electoral reforms: The case of Taiwan. Government and Opposition, 49(4), 658-681.

Dahl, R.A. (1971). Polyarchy: Participation and opposition. New Haven: Yale University Press.

Dettman, S. \& Gomez, E.T. (2019). Political financing reform: Politics, policies and patronage in Malaysia. Journal of Contemporary Asia, 49, 1-20.

Dewan Negara Malaysia (2019). Perbahasan rang undang-undang Perlembagaan (Pindaan) 2019. Parlimen Keempat Belas Penggal Kedua. Penyata Rasmi Parlimen Dewan Negara, 2(15), 20 79.

Dewan Rakyat Malaysia (2019). Usul Perdana Menteri: Rang undang-undang Perlembagaan (pindaan) 2019. Parlimen Keempat Belas Penggal Kedua. Penyata Rasmi Dewan Rakyat, 2(30), 45-170.

Elklit, J. \& Svensson, P. (1997). What makes elections free and fair? Journal of Democracy, 8(3), 3246.

Hall, T.E. (2013). US registration reform. Electoral Studies, 32(4), 589-596.

Hellmann, O. (2014). Electoral reform in Asia: Institutional engineering against 'money politics'. Japanese Journal of Political Science, 15(2), 275-298.

Irwan Muhammad Zain (2020). MPN anggap cadangan perkenalkan sistem perwakilan berkadar untungkan DAP. Astro Awani, 12 Februari. http://www.astroawani.com/berita-malaysia/mpnanggap-cadangan-perkenalkan-sistem-perwakilan-berkadar-untungkan-dap-230531

Katz, R.S. (2005). Why are there so many (or so few) electoral reforms? In Gallagher, M. \& Mitchell, P. (eds.). The politics of electoral systems (pp. 57-76). Oxford: Oxford University Press.

Khoo, Ying Hooi (2014). Electoral reform movement in Malaysia. Suvannabhumi, 6(2), 85-106.

Khoo, Ying Hooi (2016). Malaysia's 13th general elections and the rise of electoral reform movement. Asian Politics \& Policy, 8(3), 418-435.

Leyenaar, M. \& Hazan, R.Y. (2011). Reconceptualising electoral reform. West European Politics, $34(3), 437-455$.

Lyons, T. (2002). Elections to end conflict: War termination, democratization and international policy. In Mcmahon, E.R. \& Sinclair, T.A.P. (eds.). Democratic institution performance: Research and policy perspectives (pp. 125-137). Westport: Praeger Publisher.

Mahdzir Khalid (2021, 9 October). Minister of rural development, interview at his office.

Mohamad Sabu (2021, 26 September). Former defense minister and MP for Kota Raja, interview at Times Square. 
Mohd Nasaruddin Parzi (2019). Kerjasama semua pihak elak SPR 'kepenatan'. Berita Harian, 11 September. https://www.bharian.com.my/rencana/komentar/2019/09/605748/ kerjasama-semuapihak-elak-spr-kepenatan

Morgenbesser, L. \& Pepinsky, T.B. (2018). Elections as causes of democratization: Southeast Asia in comparative perspective. Comparative Political Studies, 52(1), 3-35.

Norris, P. (2011). Cultural explainations of electoral reform: A policy cycle model. West European Politics, 34(3), 531-550.

Ong, Kian Ming, Kasuya, Y. \& Mori, K. (2017). Malapportionment and democracy: A curvilinear relationship. Electoral Studies, 49, 118-127.

Ostwald, K. (2013). How to win a lost election: Malapportionment and Malaysia's 2013 general election. The Round Table: The Commonweath Journal of International Affairs, 102(6), 521532.

Pakatan Harapan (2018). Buku Harapan: Membina negara memenuhi harapan. http://kempen.s3.amazonaws.com/pdf/Buku_Harapan.pdf

Perlembagaan Persekutuan (2020). Kuala Lumpur: Pesuruhjaya Penyemak Undang-Undang Malaysia.

Rahat, G. \& Hazan, R.Y. (2011). The barriers to electoral system reform: A synthesis of alternative approaches. West European Politics, 34(3), 478-94.

Stockton, H. (2010). How rules matter: Electoral reform in Taiwan. Social Science Quarterly, 91(1), 21-41.

Streb, M. J. (2008). Rethinking American electoral democracy. New York: Routledge.

Suruhanjaya Pilihan Raya (2018). Kenyataan media bilangan 62/2018: 59 kertas undi pos bagi pilihan raya kecil (PRK) DUN N.49 Sungai Kandis dikeluarkan. https://www.spr.gov.my/sites/default/files/KM\%2062.2018.pdf

Suruhanjaya Pilihan Raya (2019a). Info SPR: ahli suruhanjaya. http://www.spr.gov.my/ms/infospr/carta-organisasi/ahli-suruhanjaya

Suruhanjaya Pilihan Raya (2019b). Panduan pendaftaran MYSPRDaftar Suruhanjaya Pilihan Raya Malaysia. $\quad$ https://mysprdaftar.spr.gov.my/muat_turun/PANDUAN_PENDAF TARAN_MYSPRDAFTAR.pdf.

Suruhanjaya Pilihan Raya (2019c). Kenyataan media bilangan 71/2019: Penjelasan berkaitan Undi18. https://www.spr.gov.my/sites/default/files/KM71\%20PDF\%203.9.2019\%20 latest.pdf

Suruhanjaya Pilihan Raya (2019d). Keputusan rasmi:pilihan raya kecil Parlimen P.165 Tanjung Piai, Johor. $\quad$ https://www.spr.gov.my/sites/default/files/keputusan\% 20rasmi\%20prk\% 20tjg\%20piai.jpg

Tey, Tsun Hang (2010). Malaysia's electoral system: Government of the people? Asian Journal of Comparative Law, 5(1), 1-32.

Tokaji, D.P. (2008). Voter registration and election reform. William \& Mary Bill of Rights, 17(2), 156.

Ufen, A. (2013). Introduction: The 2013 Malaysian elections: Business as usual of part of a protracted transition? Journal of Current Southeast Asian Affairs, 32(2), 3-17.

Wong, Chin Huat (2018). Constituency delimitation and electoral authoritarianism in Malaysia. The Round Table: The Commonweath Journal of International Affairs, 107(1), 67-80. 